Revista Brasil. Bot., V.33, n.3, p.393-405, jul.-set. 2010

\title{
Fissidentaceae (Bryophyta) da Chapada da Ibiapaba, Ceará, Brasil ${ }^{1}$
}

\author{
HERMESON CASSIANO DE OLIVEIRA² e CID JOSÉ PASSOS BASTOS²,3
}

(recebido: 10 de abril de 2008; aceito: 13 de maio de 2010)

\begin{abstract}
Fissidentaceae (Bryophyta) of the Ibiapaba Plateau, Ceará, Brazil). In the floristic survey carried out in the Ibiapaba Plateau, state of Ceará, Northeast Brazil, 20 species of Fissidentaceae were found, being eight new records for the Ceará State and Fissidens cryptoneuron P. de la Varde, F. angustifolius Sull., F. lindbergii Mitt. and F. santa-clarensis Thér. for the Northeast region. Identification keys are provided for the species found, as well geographic distribution and comments on the environment, substrate and important taxonomic characters. Illustrations have been drawn for the species rarely illustrated in the literature.
\end{abstract}

Key words - floristic, geographic distribution, mountainous environments

RESUMO - (Fissidentaceae (Bryophyta) da Chapada da Ibiapaba, Ceará, Brasil). Foram encontradas na Chapada da Ibiapaba, Ceará, 20 espécies de Fissidentaceae sendo oito novas ocorrências para o Estado e Fissidens cryptoneuron P. de la Varde, F. angustifolius Sull., F. lindbergii Mitt. e F. santa-clarensis Thér. para a Região Nordeste. São fornecidas chaves de identificação para as espécies encontradas, bem como distribuição geográfica e comentários referentes a ambiente, substrato e caracteres taxonômicos importantes. Ilustrações foram feitas para as espécies pouco ilustradas na literatura.

Palavras-chave - ambientes serranos, distribuição geográfica, florística

\section{Introdução}

A família de musgos Fissidentaceae é amplamente distribuída em todo o mundo. É monotípica, possuindo apenas o gênero Fissidens Hedw., caracterizado pelos filídios dísticos e presença de lâmina vaginante, com cerca de 500 espécies (Gradstein et al. 2001). Quanto ao padrão de crescimento do esporófito, a maioria das espécies é acrocárpica, onde o esporófito desenvolve-se no ápice de um ramo principal, mas também existem representantes cladocárpicos, onde o esporófito cresce no ápice de ramos secundários. No Brasil, Fissidentaceae está bem representada, sendo que das 93 espécies citadas para o Neotrópico, 68 ocorrem no país (Pursell 2008).

A região da Chapada da Ibiapaba possui condições ambientais que favorecem o desenvolvimento da flora briofítica. Segundo Souza (1989), a região é um dos mais importantes compartimentos geomorfológicos do território cearense. Sua porção norte consta de condições geoclimáticas que propiciam formação de brejos de cimeira e de encosta, caracterizados pela mata úmida (Fernandes 1990). Exatamente nesses ambientes, verifica-se a maior representatividade das briófitas,

1. Parte da dissertação de mestrado do primeiro autor, Programa de Pós-Graduação em Botânica, Universidade Estadual de Feira de Santana, BA, Brasil.

2. Universidade Federal da Bahia, Instituto de Biologia, Departamento de Botânica, Laboratório de Taxonomia de Briófitas, câmpus Ondina, 40170-280 Salvador, BA, Brasil.

3._Autor para correspondência: cjpbasto@ufba.br o que torna o grupo de importância relevante para a biodiversidade. A grande diversidade biológica nesses remanescentes ao lado das ameaças a que se encontram sujeitos torna essas áreas prioritárias para estudos desta natureza.

Estudos referentes à brioflora cearense citam 16 espécies de Fissidentaceae mas não abrangem de maneira significativa a região da Chapada da Ibiapaba. Com exceção de Oliveira \& Alves (2007) que fizeram um levantamento das briófitas do Município de Ubajara, situado na porção central da Chapada, os trabalhos que focaram especificamente as briófitas do Ceará citam poucas amostras coletadas esporadicamente na região da Ibiapaba. As áreas mais efetivamente estudadas são as regiões mais próximas à capital do Estado, que abrangem as Serras de Maranguape, Guaramiranga, Pirapora, Baturité e Chapada do Araripe (Brito \& Pôrto 2000, Yano \& Pôrto 2006).

Existem também trabalhos que citam espécies ocorrentes no Estado do Ceará, mas nenhum apresenta um levantamento específico e sistemático das briófitas do Estado, como é o caso dos catálogos de Yano (1981, 1984a, 1989, 1995, 1996, 2006) e os trabalhos de Vital \& Pursell (1992), Yano \& Costa (1992) e Schäfer-Verwimp \& Giancotti (1993). Há ainda registro de espécies para o Ceará nos trabalhos de briófitas para a região Nordeste realizado por Pôrto (1996).

Este trabalho teve como objetivo contribuir para o conhecimento da diversidade da família Fissidentaceae na Chapada da Ibiapaba, uma área com quase total 
ausência de estudos relacionados ao grupo das briófitas, bem como enriquecer os dados referentes à brioflora do Estado do Ceará e do Brasil.

\section{Material e métodos}

A Chapada da Ibiapaba inicia-se a $40 \mathrm{~km}$ do litoral e vai aos limites ocidentais do estado, separando o Ceará do Piauí. Possui uma extensão de $110 \mathrm{~km}$ com altitudes que variam de 800 a 1.100 m. A vegetação predominante é a Caatinga, mas outros três tipos vegetacionais são encontrados na região: a Floresta Subperenifólia Tropical Plúvio-Nebular (Mata Úmida, Serrana), a Floresta Subcaducifólia Tropical Pluvial (Mata Seca) e o Carrasco (Figueiredo 1997).

As excursões de coleta foram realizadas em fragmentos de mata e em áreas de cachoeira no período de agosto de 2006 a junho de 2007, nos Municípios de Guaraciaba do Norte, Viçosa do Ceará e Ubajara, além de coletas adicionais nos Municípios de Tianguá, Ibiapina e Ipu, seguindo a metodologia usual descrita em Yano (1984b). Foram analisadas também amostras depositadas no Herbário Francisco José de Abreu Matos (HUVA) da Universidade Estadual Vale do Acaraú, localizada no Município de Sobral, Ceará.

Para a identificação das amostras, foram utilizados os trabalhos de Florschütz (1964), Lisboa (1993, 1994), Oliveirae-Silva \& Yano (2000), Sharp et al. (1994) e Pursell (2008) além de comparação com material de herbário.

A distribuição geográfica das espécies foi baseada nos trabalhos de Yano (1981, 1989, 1995, 2006), Yano \& Pôrto (2006) e Oliveira \& Alves (2007). Grupos briocenológicos aqui são entendidos como as comunidades que crescem em dados substratos (Fudali 2001): corticícola (tronco vivo), epíxila (tronco morto), terrícola (solos), casmófita (substrato artificial - concreto ou argamassa) e epimiconte (fungos não liquenizados); espectro ecológico é entendido como a variabilidade de substratos colonizados, consoante os grupos briocenológicos (Fudali 2000).

As amostras foram depositadas nos Herbários HUEFS (Herbário da Universidade Estadual de Feira de Santana, Feira de Santana, Bahia), ALCB (Herbário Alexandre Leal Costa, Instituto de Biologia da Universidade Federal da Bahia, Salvador, Bahia) e HUVA (Herbário Francisco José de Abreu Matos da Universidade Estadual Vale do Acaraú, Sobral, Ceará).

As espécies estão organizadas em ordem alfabética e, para cada uma, são fornecidos distribuição geográfica mundial e brasileira e comentários referentes a ambiente, substrato e caracteres taxonômicos importantes. Foram ilustradas aquelas espécies que contam com poucas ilustrações na literatura. As novas ocorrências para o Estado do Ceará estão assinaladas com um asterisco $(*)$.

\section{Resultados e discussão}

Foram encontradas 20 espécies pertencentes à família Fissidentaceae, destas, oito são novas para o Estado do Ceará, quatro são referidas pela primeira vez para a região Nordeste, e Fissidens cryptoneuron P. de la Varde está sendo citada pela segunda vez para o Neotrópico e para o Brasil (Pursell 2008).

\section{FISSIDENTACEAE}

Chave para as espécies de Fissidentaceae encontradas na Chapada da Ibiapaba

1. Limbídia presente ao menos nos filídios periqueciais

2. Limbídia percorrendo toda a extensão da lâmina

3. Células da lâmina lisas

4. Células laxas

5. Filídios com apículo vermelho, costa terminando 8-10 células abaixo do ápice Fissidens lindbergii

5. Filídios sem apículo vermelho, costa terminando 5-6 células abaixo do ápice Fissidens flaccidus

4. Células não laxas

6. Filídios lanceolados, células da lâmina, em vista superficial, infladas

6. Filídios ovalado-lanceolados, células da lâmina não infladas Fissidens zollingeri

3. Células da lâmina unipapilosas Fissidens anguste-limbatus

2. Limbídia terminando próximo ao ápice ou restrita à região basal do filídio

7. Limbídia terminando próximo ao ápice, células da lâmina hexagonais a quadráticas, lisas Fissidens crispus

7. Limbídia restrita à base, pelo menos nos filídios periqueciais, células da lâmina hexagonais ou arredondadas, papilosas

8. Células da lâmina pluripapilosas Fissidens guianensis

8. Células da lâmina unipapilosas 
9. Células da lâmina arredondadas, lâmina vaginante com limbídia intramarginal Fissidens intromarginatus

9. Células da lâmina quadráticas a hexagonais, lâmina vaginante com limbídia atingindo a metade ou acima, nunca intramarginal

1. Limbídia ausente

10. Células da lâmina grandes, 15-65 $\mu \mathrm{m}$ compr., lisas Fissidens submarginatus

10. Células da lâmina pequenas, menores que $15 \mu \mathrm{m}$ compr., papilosas ou mamilosas

11. Filídios com ápice obtuso ou levemente acuminado

12. Células da lâmina pluripapilosas

13. Células da região basal da lâmina vaginante longo-retangulares

13. Células da região basal da lâmina vaginante não diferenciadas Fissidens ramicola

12. Células da lâmina mamilosas

14. Lâmina vaginante ultrapassando a metade do comprimento do filídio ... Fissidens asplenioides

14. Lâmina vaginante se estendendo até a metade do comprimento do filídio ou abaixo

15. Filídios caducos Fissidens radicans

15. Filídios não caducos Fissidens santa-clarensis

11. Filídios com ápice acuminado ou apiculado

16. Filídios com margem inteira, levemente serrulada no ápice, células da lâmina lisas Fissidens pellucidus

16. Filídios com margem crenulada ou denteada, células da lâmina papilosas ou mamilosas

17. Filídios com costa encoberta na porção superior por uma camada células da lâmina Fissidens cryptoneuron

17. Filídios com costa não encoberta por uma camada de células da lâmina

18. Células da lâmina unipapilosas

19. Células da lâmina pentagonais a hexagonais, menores nas margens, retangulares próximo à porção basal da costa Fissidens hornschuchii

19. Células da lâmina irregularmente hexagonais, não diferenciadas nas margens, retangulares na base Fissidens serratus

18. Células da lâmina mamilosas Fissidens prionodes

*Fissidens anguste-limbatus Mitt., J. Linn. Soc., Bot. 12: 601.1869.

Figura 1a-e

Descrição: Pursell (2008)

Material examinado: BRASIL. CEARÁ: Ubajara, Cachoeira do Frade, 6-III-2007, H.C. Oliveira 702, 706 (HUEFS); Ipu, Bica do Ipu, 10-III-2007, H.C. Oliveira 643 (HUEFS).

Distribuição geográfica: Américas do Norte, Central e do Sul. No Brasil: AC, AM, MT, MG, PA, PR, PE, RJ, RS, RO, RR, SC e SP. Amplamente distribuída no país, ocorrendo em todas as regiões.

Encontrada próximo a queda d'água, crescendo sobre barranco. Segundo Pursell (2008) pode ser encontrada também submersa em rios e riachos. A espécie é facilmente reconhecida pelos filídios largos, com bordo forte em toda a extensão da lâmina e células pequenas e lisas.
*Fissidens angustifolius Sull., Proc. Amer. Acad. 5: 275. 1861.

Figura 1f-k

Descrição: Pursell (2008)

Material examinado: BRASIL. CEARÁ: Ubajara, Parque Nacional de Ubajara, 6-III-2007, H.C. Oliveira 770 (HUEFS); Ipu, Bica do Ipu, 10-III-2007, H.C. Oliveira 672, 675, 679, 688, 694 (HUEFS); Ubajara, Parque Nacional de Ubajara, 29-V-2007, H.C. Oliveira 992, 1025 (HUEFS).

Distribuição geográfica: Américas do Norte, Central e do Sul, Ásia e Ilhas do Pacífico. No Brasil: AM, PA, RO, e SP. Tendo sido citada para as regiões Norte e Sudeste, a espécie apresenta uma distribuição descontínua no Brasil, o que demonstra a necessidade de mais coletas nas outras regiões. Esta é a primeira citação para a região Nordeste.

Encontrada na mata e próximo a quedas d'água, sobre troncos de árvores, rochas úmidas e solo, crescendo 


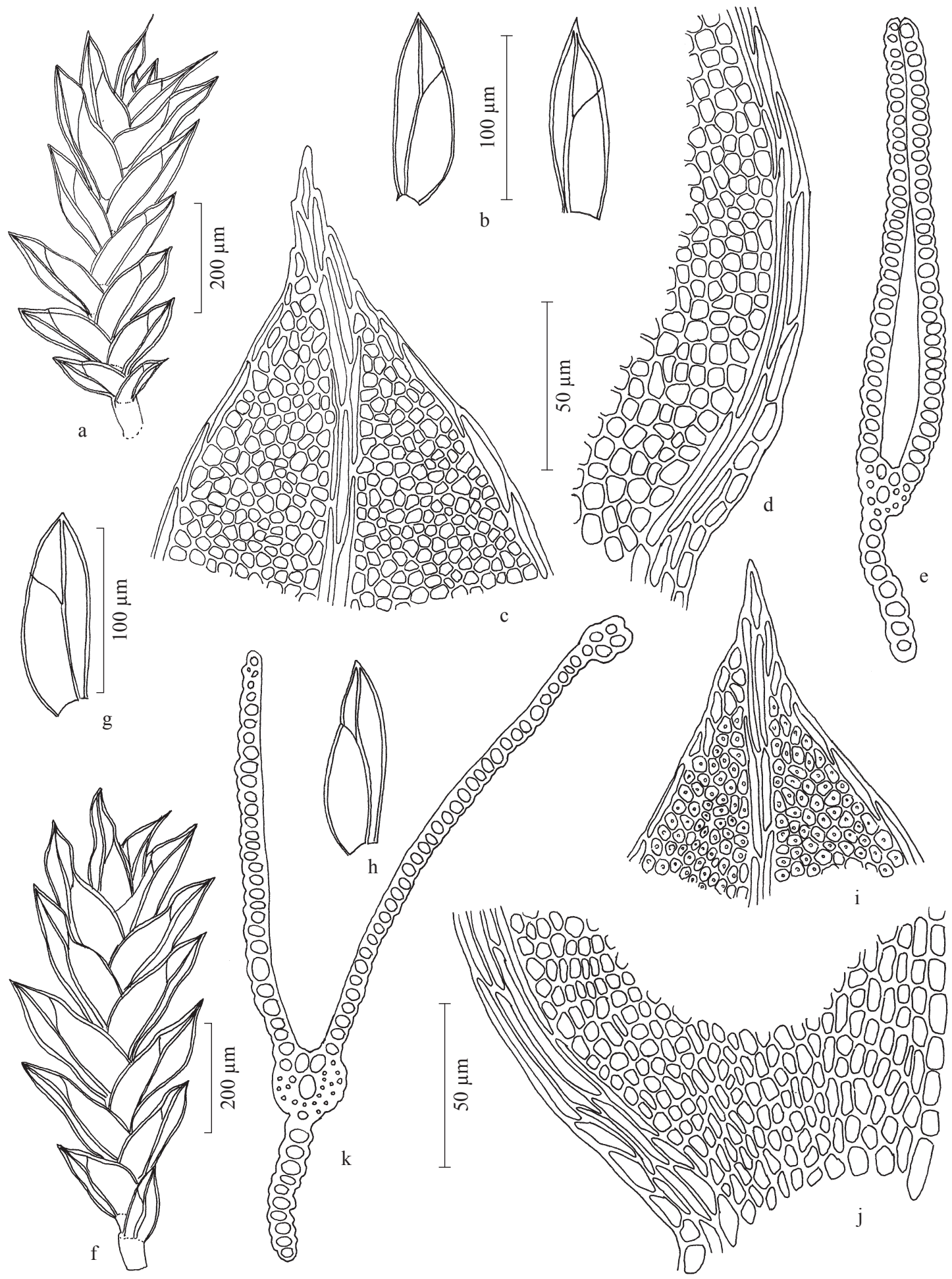

Figura 1. a-e. Fissidens anguste-limbatus. a. Aspecto geral do gametófito. b. Filídios. c. Células do ápice do filídio. d. Células da base do filídio. e. Secção transversal do filídio. f-k. F. angustifolius Sull. f. Aspecto geral do gametófito. g-h. Filídios. i. Células do ápice do filídio. j. Células da base do filídio. k. Secção transversal do filídio.

Figure 1 a-e. Fissidens anguste-limbatus. a. Aspect of the gametophyte. b. Leaves. c. Apical cells of the leaf. d. Basal cells of the leaf. e. Cross section of the leaf. f-k. F. angustifolius. f. Aspect of the gametophyte. g-h. Leaves. i. Apical cells of the leaf. j. Basal cells of the leaf. k. Cross section of the leaf. 
associada à F. lindbergii Mitt., Bryum mattogrossense Broth. e Philonotis cernua (Wilson) D.G. Griffin \& W.R. Buck. Segundo Pursell (2008), pode ser encontrada sobre solo, rochas calcárias e troncos caídos na mata. A espécie já foi incluída no conceito de $F$. zollingeri Mont. (citada como Fissidens kegelianus C.M.) no trabalho de Florschütz (1964), entretanto, segundo Sharp et al. (1994) é possível distingui-las pelas células unipapilosas presentes em $F$. angustifolius e ausentes em F. zollingeri. F. angustifolius caracteriza-se ainda pelos filídios estreitos com margem inteira e limbídia percorrendo toda a extensão da lâmina

*Fissidens asplenioides Hedw., Sp. Musc. 156. 1801. Figura 2a-e

Descrição: Pursell (2008)

Material examinado: BRASIL. CEARÁ: Ubajara, Sítio São Luis, 0347’90” S, 4054’32” W, 8-VIII-2006, H.C. Oliveira 443 (HUEFS).

Distribuição geográfica: Pantropical. No Brasil: BA, ES, MG, PR, RJ, RS, RR, SC e SP.

Encontrada na mata, crescendo sobre rochas em ambiente sombreado. Conforme Pursell (2008), a espécie pode ser encontrada colonizando solos de florestas, barrancos e rochas próximos a fluxos d'água, perto de cachoeiras e, mais raramente, sobre troncos de árvores. A planta apresenta filídios enrolados para dentro quando secos. De acordo com Sharp et al. (1994) esta característica, o grande tamanho da planta e a lâmina vaginante livre com células da margem diferenciadas, auxiliam na identificação desta espécie. Fissidens asplenioides caracteriza-se ainda pelos filídios com margem crenulada, ápice obtuso a acuminado, costa forte subpercurrente, células da lâmina mamilosas e lâmina vaginante ultrapassando a metade do comprimento do filídio.

*Fissidens crispus Mont., Ann. Sci. Nat. Bot. II, 9: 57. 1838.

Figura 2f-j

Descrição: Pursell (2008)

Material examinado: BRASIL. CeArÁ: Tianguá, estrada entre Frecherinha e Tianguá, 8-V-2006, H.C. Oliveira 361, 363 (HUEFS); Viçosa do Ceará, CE 232, km 127, 8-V-2006, H.C. Oliveira 373 (HUEFS); Ipu, Bica do Ipu, 10-III-2007, H.C. Oliveira 669 (HUEFS); Viçosa do Ceará, Fonte do Caranguejo, 5-VI-2007, H.C. Oliveira 1063, 1077 (HUEFS).
Distribuição geográfica: Américas do Norte, Central e do Sul e Ásia. No Brasil: AM, BA, PR, RS, SC e SP. A espécie apresenta distribuição descontínua, sendo citada para as regiões Norte, Nordeste, Sul e Sudeste do Brasil.

Encontrada próximo a quedas d'água, crescendo sobre rochas e barrancos úmidos, associada à Fissidens serratus Müll. Hal. De acordo com Pursell (2008), pode ocorrer ainda colonizando troncos e ramos vivos ou em decomposição. Sharp et al. (1994) caracteriza a espécie pelos filídios crispados, com margens mais ou menos inteiras e costa percurrente. Fissidens crispus caracterizase ainda pela limbídia terminando próximo ao ápice e células da lâmina irregularmente hexagonais a quadráticas, lisas, retangulares próximo à porção inferior da costa.

*Fissidens cryptoneuron P. de la Varde, Rev. Bryol. Lichénol. 5: 208. 5. 1933.

Figura 3a-f.

Descrição: Pursell (2008)

Material examinado: BRASIL. CEARÁ: Ubajara, Sítio São Luis, 0347'90” S, 4054’32” W, 29-IV-2004, H.C. Oliveira 161 (HUVA).

Distribuição geográfica: África Tropical e Madagascar. No Brasil: MG. Esta espécie apresenta uma interessante disjunção em sua distribuição. Esta corresponde a sua segunda citação para o Neotrópico e primeira para a região Nordeste do Brasil.

Encontrada na mata, sobre troncos de árvores. Segundo Pursell (2008) a espécie só foi encontrada sobre troncos de árvores. Os filídios com margem crenulada, ápice apiculado, células pluripapilosas e a costa forte, subpercurrente, obscura, encoberta por uma camada de pequenas células da lâmina, caracterizam a espécie. A espécie já foi citada erroneamente para o Estado do Ceará como F. obscurocostatus por Oliveira \& Alves (2007), no entanto esta possui células mamilosas e apenas a porção superior da costa é obscura.

Fissidens flaccidus Mitt., Trans. Linn. Soc. London. 23: 56. 1860.

Descrição e ilustração: Pursell (2008)

Material examinado: BRASIL. CEARÁ: Viçosa do Ceará, Fonte do Caranguejo, 5-VI-2007, H.C. Oliveira 1059, 1076, 1085, 1098 (HUEFS).

Distribuição geográfica: Américas Central e do Sul e Ilhas Ocidentais. No Brasil: AC, BA, CE, MT, MS, MG, PA, PB, PR, PE, RJ, RO e SP. A espécie é amplamente distribuída no Brasil. 

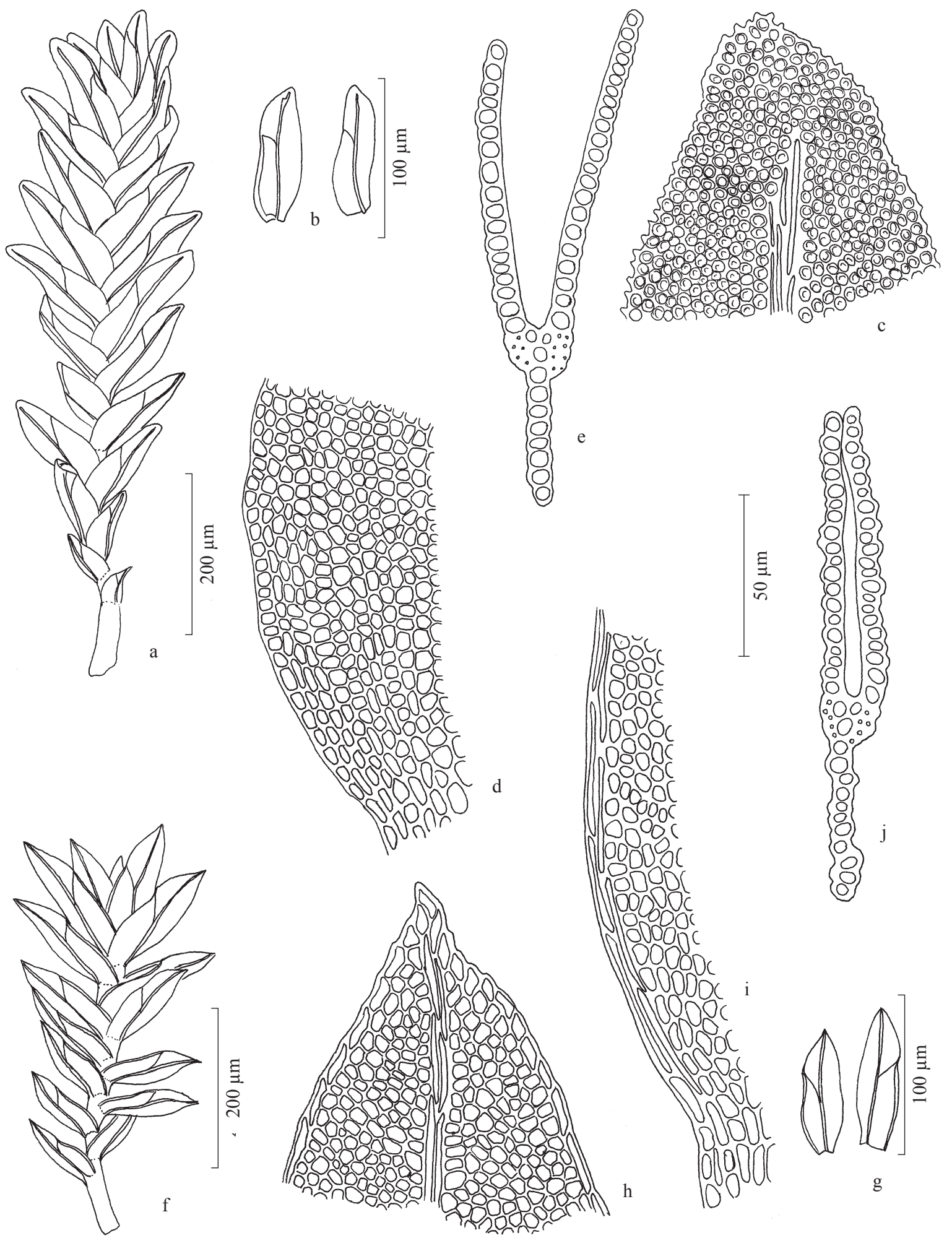

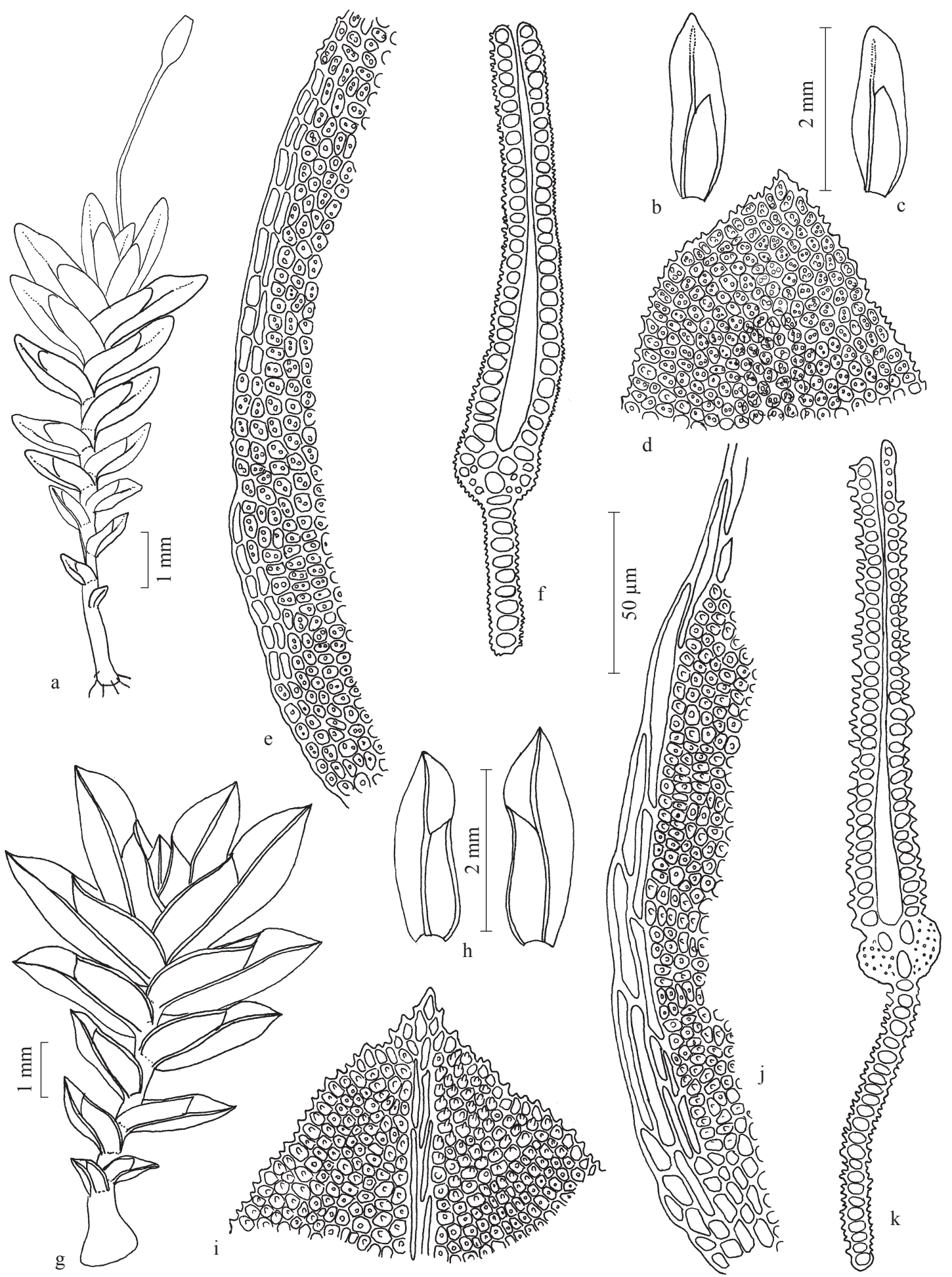

Figura 3. a-f. Fissidens cryptoneuron. a. Aspecto geral do gametófito. b-c. Filídios. d. Células do ápice do filídio. e. Células da base do filídio. f. Secção transversal do filídio. g-k. F. submarginatus. g. Aspecto geral do gametófito. h. Filídios. i. Células do ápice do filídio. j. Células da base do filídio. k. Secção transversal do filídio.

Figure 3. a-f. Fissidens cryptoneuron. a. Aspect of the gametophyte. b-c. Leaves. d. Apical cells of the leaf. e. Basal cells of the leaf. f. Cross section of the leaf. g-k. F. submarginatus. g. Aspect of the gametophyte. h. Leaves. i. Apical cells of the leaf. j. Basal cells of the leaf. k. Cross section of the leaf. 
Encontrada na mata próximo a quedas d'água, sobre rocha úmida, crescendo associada à $F$. serratus Müll. Hal. e Philonotis hastata (Duby) Wijk \& Margad. Pursell (2008) acrescenta ainda que a espécie pode ser encontrada sobre solos úmidos, rochas, ramos caídos e troncos de árvores, frequentemente ao longo de córregos e próximo a cachoeiras. A espécie é próxima de $F$. lindbergii Mitt. diferenciando-se pelos filídios flácidos, costa terminando próximo ao ápice e pela ausência de apículo vermelho, característico de F. lindbergii Mitt.

Fissidens guianensis Mont., Ann Sci. Nat. Bot. sér. 2, 14: 340. 1840.

Figura $4 \mathrm{a}-\mathrm{f}$

Descrição: Pursell (2008)

Material examinado: BRASIL. CeArÁ: Ubajara, Sítio São Luis, 0347'90” S, 4054’32” W, 31-X-2003, H.C. Oliveira 122 (HUVA); idem, Parque Nacional de Ubajara, 6-III-2007, H.C. Oliveira 734 (HUEFS); idem, 29-V-2007, H.C. Oliveira 966, 973, 985, 1005, 1030, 1031, 1033, 1039 (HUEFS).

Distribuição geográfica: Américas Central e do Sul. No Brasil: AM, CE, ES, GO, MT, MS, PA, PE, PI, RJ, RO, SP e TO. A espécie é amplamente distribuída no Brasil.

Encontrada na mata e próximo às quedas d'água, crescendo sobre troncos vivos e em decomposição e sobre rochas em ambiente sombreado, associada à F. serratus Müll. Hal., F. santaclarensis Thér. e Philonotis hastata (Duby) Wijk \& Margad. A espécie é muito variável, dificultando sua definição. Florschütz (1964) acrescenta que os únicos caracteres confiáveis para separar $F$. guianensis de outras espécies relacionadas são as células apicais e dorsais uni ou pluripapilosas da lâmina e as células da lâmina vaginante sempre finamente pluripapilosas. Esses caracteres foram úteis na identificação do material estudado no presente trabalho. Uma variação freqüente foi a presença ou ausência da limbídia, muitas vezes presente apenas nos filídios periqueciais.

Fissidens hornschuchii Mont., Ann. Sci. Nat. Bot. sér. 2, 14: 342. 1840.

Descrição e ilustração: Pursell (2008)

Material examinado: BRASIL. CEARÁ: Viçosa do Ceará, Fonte do Caranguejo, 5-VI-2007, H.C. Oliveira 938, 949 (HUEFS).

Distribuição geográfica: México, Américas Central e do Sul. No Brasil: AM, CE, ES, GO, MG, MT, PA, PE, PR, RJ, RO, RS e SP. Amplamente distribuída no Brasil.
Encontrada na mata próximo a queda d'água, crescendo sobre rocha úmida. Segundo Pursell (2008) ocorre sobre solos, rochas, ramos e troncos de árvores. A espécie caracteriza-se pelos filídios com margem crenulada, células da lâmina hexagonais, unipapilosas, menores nas margens e retangulares próximo à porção inferior da costa.

*Fissidens inaequalis Mitt., Journ. Linn. Soc. London Bot. 12: 589. 1869.

Descrição e ilustração: Pursell (2008)

Material examinado: BRASIL. CeArÁ: Tianguá, estrada entre Frecherinha e Tianguá, 8-V-2006, H.C. Oliveira 359 (HUEFS); Ubajara, Parque Nacional de Ubajara, 6-III-2007, H.C. Oliveira 768 (HUEFS).

Distribuição geográfica: Américas Central e do Sul. No Brasil: AC, BA, AM, PA, PE, RJ, RO, RR e SC. Apresenta distribuição descontínua no Brasil, ocorrendo nas regiões Norte, Nordeste, Sul e Sudeste.

Encontrada na mata e próximo a quedas d'água, sobre solo e barranco, associada à Fissidens pellucidus Hornsch. e Fissidens prionodes Mont. Pode ocorrer ainda sobre troncos e ramos caídos na mata e ocasionalmente sobre rochas e térmites (Pursell 2008). A espécie é caracterizada pelas células grandes, lisas, com formas irregulares variando de retangulares a longo-hexagonais.

Fissidens intromarginatus (Hampe) A. Jaeger, Enum. Fissident. 14. 1869.

Descrição e Ilustração: Pursell (2008)

Material examinado: BRASIL. CEARÁ: Ubajara, Parque Nacional de Ubajara, 6-III-2007, H.C. Oliveira 733, 799 (HUEFS).

Distribuição geográfica: México, Américas Central e do Sul e África. No Brasil: AC, CE, ES, GO, MG, MT, MS, PA, PR, RO, RJ, RS, SC e SP. Amplamente distribuída no Brasil.

Encontrada na mata, sobre tronco de árvore, crescendo associada à Fissidens santaclarensis Thér. No entanto, de acordo com Pursell (2008), Fissidens intromarginatus é raramente encontrada colonizando troncos de árvores, ocorrendo mais comumente sobre solos e rochas ao longo de córregos. A espécie se caracteriza pelos filídios com margem crenulada, ápice agudo, costa percurrente, células da lâmina arredondadas, unipapilosas e pela lâmina vaginante com limbídia parcialmente inserida entre as células medianas e marginais. 
*Fissidens lindbergii Mitt., Journ. Linn. Soc. Bot. 12: 602. 1869.

Figura $4 \mathrm{~g}-\mathrm{k}$

Descrição: Pursell (2008)

Material examinado: BRASIL. CeArÁ: Tianguá, estrada entre Frecherinha e Tianguá, 8-V-2006, H.C. Oliveira 362 (HUEFS); Ubajara, Parque Nacional de Ubajara, 6-III-2007, H.C. Oliveira 815 (HUEFS); Ipu, Bica do Ipu, 10-III-2007, H.C. Oliveira 684, 694 (HUEFS); Viçosa do Ceará, Fonte do Caranguejo, 5-VI-2007, H.C. Oliveira 933 (HUEFS).

Distribuição geográfica: Américas Central e do Sul e Ilhas Ocidentais. No Brasil: GO e RJ. Os poucos registros para o Brasil demonstram a necessidade de mais coletas nas diversas regiões do país. Esta é a primeira citação para a região Nordeste.

Encontrada na mata e próximo a quedas d'água, sobre piso de cimento, rochas e barrancos úmidos em ambientes semi-ensolarados, crescendo associada à Fissidens angustifolius e Fissidens crispus. A ocorrência sobre substratos de cimento e tijolos é citada como rara por Pursell (2008). A espécie é próxima de Fissidens flaccidus, distinguindo-se pela costa mais curta e pela célula apical vermelha.

Fissidens pallidinervis Mitt., J. Linn. Soc., Bot. 12: 592. 1869.

Descrição e ilustração: Pursell (2008)

Material examinado: BRASIL. CEARÁ: Ubajara, Sítio São Luis, 0347’90” S, 4054’32” W, 29-IV-2004, H.C. Oliveira 208 (HUVA).

Distribuição geográfica: Américas do Norte, Central e do Sul, Japão, Índia, Nepal e Ilhas Filipinas. No Brasil: CE, GO, MT, PA e SP.

Encontrada na mata, crescendo sobre rochas em ambiente sombreado. Segundo Pursell (2008) pode ocorrer sobre troncos de árvores vivos ou em decomposição, solos e térmites. A espécie é facilmente reconhecida pelo pequeno tamanho do gametófito (até $9 \mathrm{~mm}$ compr.), células da lâmina pequenas, obscuras, pluripapilosas e pelo ápice agudo a obtuso.

Fissidens pellucidus Hornsch., Linnaea 15: 146. 1841.

Descrição e ilustração: Pursell (2008)

Material examinado: BRASIL. CEARÁ: Guaraciaba do Norte, mata fresca, $04^{\circ} 06^{\prime} 43^{\prime}$ ' S, 4049'28” W, 7-IX-2006, H.C. Oliveira 460 (HUEFS); Ubajara, Parque Nacional de Ubajara, 6-III-2007, H.C. Oliveira 768, 814 (HUEFS).
Distribuição geográfica: Américas do Norte, Central e do Sul, Japão, Austrália e Nova Caledônia. No Brasil: AM, BA, CE, DF, MG, MT, PA, PR, RJ, RO, RR, SC, SP e TO. Amplamente distribuída no Brasil.

Encontrada na mata e próximo a quedas d'água, sobre solo e rochas, crescendo associada à Dicranodontium pulchroalare subsp. brasiliense (Herzog) J.-P. Frahm. Pode ocorrer sobre solos, térmites, rochas, troncos em decomposição e, mais raramente, sobre troncos de árvores (Pursell 2008). A espécie distingue-se pela coloração avermelhada do gametófito, células da lâmina moderadamente grandes, hexagonais, lisas e pelúcidas.

Fissidens prionodes Mont., Ann. Sci. Nat. Bot. sér. 2, 3: 200. 1835.

Descrição e ilustração: Pursell (2008)

Material examinado: BRASIL. CEARÁ: Tianguá, estrada entre Frecherinha e Tianguá, 8-V-2006, H.C. Oliveira 346, 359 (HUEFS); Ubajara, Sítio São Luis, 0347'90" S, 4054'32” W, 8-VIII-2006, H.C. Oliveira 440, 441, 444, 445 (HUEFS); Viçosa do Ceará, Fonte do Caranguejo, 5-VI-2007, H.C. Oliveira 935 (HUEFS).

Distribuição geográfica: Amplamente distribuída no Neotrópico. No Brasil: AM, BA, CE, GO, MG, MT, PA, PB, PE, PI, PR, RJ, RO, RR, RS e SP.

Encontrada próximo à quedas d'água, crescendo sobre barrancos e rochas úmidas, associada à Fissidens inaequalis, Philonotis hastata (Duby) Wijk \& Margad. e Calypogeia laxa Lindenb. \& Gottsche. Segundo Pursell (2008) pode ocorrer sobre solos, térmites e ocasionalmente sobre troncos em decomposição e em tocas de animais. Fissidens prionodes caracteriza-se pelos filídios linearlanceolados, com margem crenulada, não bordeada, ápice apiculado, costa excurrente, células da lâmina hexagonais, mamilosas e as basais retangulares.

Fissidens radicans Mont., Ann. Sci. Nat. Bot. sér. 2. 14: 345. 1840 .

Descrição e ilustração: Pursell (2008)

Material examinado: BRASIL. CEARÁ: Ubajara, Cachoeira do Poção, 10-IX-2004, H.C. Oliveira 242 (HUVA).

Distribuição geográfica: Américas do Norte, Central e do Sul e Ilhas Ocidentais. No Brasil: BA, CE, ES, MS, PA, PB, PR, PE, PI, RJ, RS e SP. Amplamente distribuída no Brasil.

Encontrada na mata, próximo a quedas d'água, crescendo sobre troncos de árvores em ambiente úmido e 
sombreado. De acordo com Pursell (2008) pode ocorrer também sobre troncos em decomposição e raramente sobre rochas. A espécie é próxima de F. santa-clarensis, antes tratada como Fissidens allenianus Brugg.-Nann. \& Pursell. Segundo Sharp et al. (1994), ambas já foram consideradas a mesma espécie, entretanto, diferenciam-se por uma série de caracteres. Fissidens radicans Mont. apresenta filídios caducos com ápice arredondado a apiculado e peristômio com dentes incompletos, enquanto que Fissidens santa-clarensis Thér. possui filídios firmes, com ápice abruptamente estreito a obtuso e peristômio com dentes completos.

Fissidens ramicola Broth., Hedwigia 45: 268. 1906.

Descrição e ilustração: Pursell (2008)

Material examinado: BRASIL. CEARÁ: Ubajara, Cachoeira do Poção, 10-IX-2004, H.C. Oliveira 287 (HUVA); idem, Parque Nacional de Ubajara, 29-V-2007, H.C. Oliveira 1027 (HUEFS).

Distribuição geográfica: México, Américas Central e do Sul e Ilhas Ocidentais. No Brasil: AM, CE e ES. A distribuição desta espécie no Brasil se apresenta de forma descontínua, não tendo sido citada para as regiões Centro-oeste e Sul.

Encontrada na mata próximo a quedas d'água, crescendo em solos e rochas úmidas. A espécie é próxima de Fissidens pallidinervis. Ambas possuem células da lâmina pluripapilosas e uma limbídia restrita à base da lâmina vaginante dos filídios periqueciais. Segundo Pursell (2008), Fissidens ramicola pode ser diferenciada pela lâmina dorsal abruptamente estreita na inserção no caulídio.

*Fissidens santa-clarensis Thér., Mem. Soc. Cub. Hist. Nat. "Felipe Poey" 13: 209. 1939.

Descrição e ilustração: Pursell (2008)

Material examinado: BRASIL. CEARÁ: Ubajara, Parque Nacional de Ubajara, 6-III-2007, H.C. Oliveira 799, 800 (HUEFS); Viçosa do Ceará, Fonte do Caranguejo, 5-VI-2007, H.C. Oliveira 939 (HUEFS); Ubajara, Parque Nacional de Ubajara, Cachoeira da Gameleira, 29-V-2007, H.C. Oliveira 976, 984, 1033 (HUEFS).

Distribuição geográfica: Américas do Norte, Central e do Sul e Ilhas Ocidentais. No Brasil: PA. Espécie com distribuição restrita no Brasil, ocorrendo apenas na Região Norte. Esta corresponde à primeira citação para a Região Nordeste.
Encontrada na mata e próximo a quedas d'água, sobre troncos de árvores e rochas úmidas, associada à Fissidens intromarginatus, Fissidens guianensis, Philonotis hastata (Duby) Wijk \& Margad. e Isopterygium tenerum (Sw.) Mitt. Pode ocorrer ainda sobre troncos e ramos em decomposição (Pursell 2008). A espécie é próxima de Fissidens radicans e, segundo Sharp et al. (1994), o qual a trata como Fissidens allenianus Brugg.-Nann. \& Pursell, diferencia-se pelos filídios persistentes, com ápice obtuso e peristômio completo. Fissidens santaclarensis caracteriza-se ainda pelos filídios com margem crenulada, não bordeada, células da lâmina hexagonais a arredondadas, mamilosas.

Fissidens serratus Müll. Hal., Bot. Zeitung (Berlin) 5: 804. 1847.

Descrição e ilustração: Pursell (2008)

Material examinado: BRASIL. CeArÁ: Ubajara, Sítio São Luís, 0347’90” S, 4054’32” W, 29-IV-2004, H.C. Oliveira 163 (HUVA); Viçosa do Ceará, Fonte do Caranguejo, 5-VI-2007, H.C. Oliveira 1072, 1076, 1077 (HUEFS); Ubajara, Parque Nacional de Ubajara, 29-V-2007, H.C. Oliveira 1039 (HUEFS).

Distribuição geográfica: Américas do Norte, Central e do Sul, África, Ásia, Madagascar, Ilhas Canárias e Java. No Brasil: CE, MG, MT, PE e SP.

Encontrada na mata e próximo a queda d'água, crescendo em solos e rochas úmidas, associada à Fissidens flaccidus, Fissidens crispus e Fissidens guianensis. A espécie é facilmente reconhecida pelos filídios com margens grosseiramente serreadas, principalmente na região da lâmina vaginante e células da lâmina mamilosas. Pursell (2008) acrescenta que Fissidens serratus pode apresentar filídios com margens mais ou menos inteira, especialmente na região da lâmina vaginante.

Fissidens submarginatus Bruch in Krauss, Flora 29: 133. 1846.

Figura 4g-k

Descrição: Pursell (2008)

Material examinado: BRASIL. CEARÁ: Ubajara, Parque Nacional de Ubajara, 6-III-2007, H.C. Oliveira 805 (HUEFS).

Distribuição geográfica: Américas do Norte, Central e do Sul, África, Ilhas Ocidentais e Havaí. No Brasil: AC, AM, BA, CE, MT, MS, PA, PE, PI, RJ, RO, SC, SP e TO. Amplamente distribuída na América do Sul e no Brasil. 


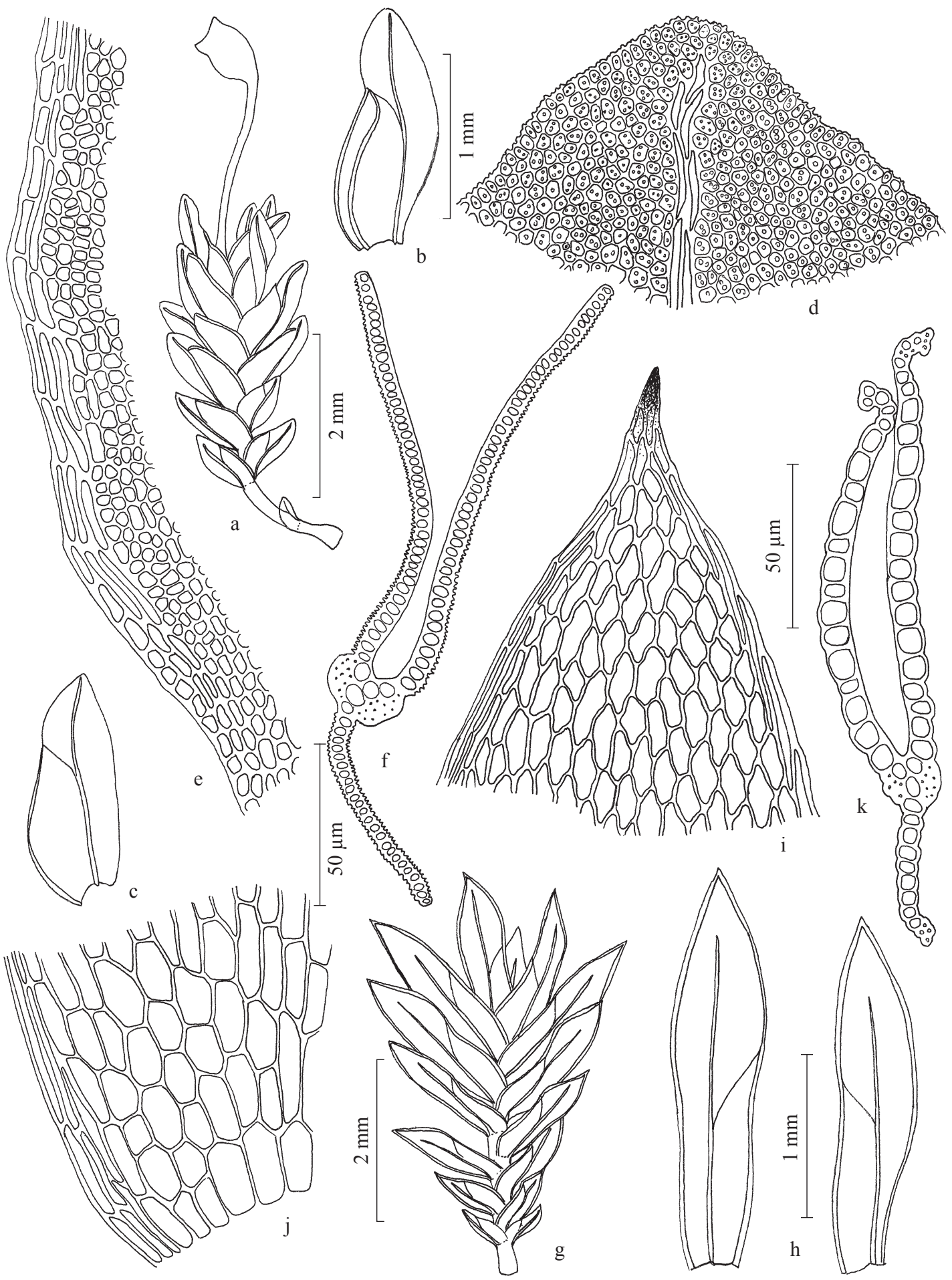

Figura 4. a-k. a-f. Fissidens guianensis Mont. a. Aspecto geral do gametófito. b-c. Filídios. d. Células do ápice do filídio. e. Células da base do filídio. f. Secção transversal do filídio. g-k. F. lindbergii Mitt. g. Aspecto geral do gametófito. h. Filídios. i. Células do ápice do filídio. j. Células da base do filídio. k. Secção transversal do filídio.

Figura 4. a-k. a-f. Fissidens guianensis Mont. a. Aspect of the gametophyte. b-c. Leaves. d. Apical cells of the leaf. e. Basal cells of the leaf. f. Cross section of the leaf. g-k. F. lindbergii Mitt. g. Aspect of the gametophyte. h. Leaves. i. Apical cells of the leaf. j. Basal cells of the leaf. k. Cross section of the leaf. 
Encontrada na mata, crescendo sobre troncos de árvores em ambiente sombreado. Pode ocorrer ainda sobre solos, rochas, ocasionalmente sobre térmites e raízes expostas (Pursell 2008). A espécie caracteriza-se pelas células unipapilosas e pela limbídia restrita à região da lâmina vaginante. De acordo com Pursell (2008) F. submarginatus pode apresentar algumas células com duas papilas e lâmina vaginante com limbídia curta.

Fissidens zollingeri Mont., Ann. Sci. Nat. Bot. sér. 3, 4: 114. 1845.

Descrição e ilustração: Pursell (2008)

Material examinado: BRASIL. CEARÁ: Ubajara, Sítio São Luis, 0347’90” S, 4054’32” W, 29-IV-2004, H.C. Oliveira 201 (HUVA).

Distribuição geográfica: Américas do Norte, Central e do Sul, África, Ásia e Ilhas do Pacífico. No Brasil: AC, AM, BA, CE, ES, FN, GO, MA, MG, MS, PA, PB, PE, PI, PR, RJ, RO, SC, SP, e TO. Largamente distribuída em todo o Neotrópico. No Brasil, ocorrendo em quase todos os estados.

Encontrada na mata, crescendo sobre solo em ambiente sombreado. Segundo Pursell (2008) pode ocorrer ainda sobre troncos em decomposição, rochas calcárias, ocasionalmente na base de troncos de árvores e sobre térmites. A espécie caracteriza-se pela coloração verde-pálida do gametófito, limbídia forte em toda a extensão da lâmina, células lisas na porção superior e maiores, oblongas, com paredes espessas e pelúcidas na lâmina vaginante.

A maioria das espécies encontradas possui distribuição ampla, ocorrendo no Brasil desde a região Norte até a Sul, com exceção de Fissidens cryptoneuron, citada apenas para o Estado de Minas Gerais, configurando-se como segunda citação para o Brasil e primeira para a região Nordeste, juntamente com $F$. angustifolius, F. lindbergii e $F$. santa-clarensis, sendo a última citada preteritamente apenas para o Estado do Pará (Lisboa \& Ilkiu-Borges 1997). Em adição, F. anguste-limbatus, F. asplenioides, F. crispus e $F$. inaequalis totalizam oito ocorrências novas para o estado do Ceará.

O espectro ecológico obtido foi rupícola - terrícola - corticícola - epixílica - casmófita, onde o grupo briocenológico rupícola foi predominante, sendo rocha o substrato preferencial.

Diante dos resultados obtidos, nota-se a riqueza de espécies da família Fissidentaceae na Chapada da Ibiapaba. Um número tão elevado e a quantidade de áreas ainda não coletadas na região, principalmente os fragmentos de Mata Atlântica, revelam a necessidade de aprofundamento dos estudos de briófitas na área.

Agradecimentos - Os autores agradecem à Universidade Estadual de Feira de Santana (UEFS), ao Programa de PósGraduação em Botânica, à Coordenação de Aperfeiçoamento de Pessoal de Nível Superior (Capes) pela bolsa concedida ao primeiro autor, ao Instituto Brasileiro do Meio Ambiente e dos Recursos Naturais Renováveis (Ibama) pela licença concedida para realização de coletas no Parque Nacional de Ubajara, ao Herbário HUVA da Universidade Estadual Vale do Acaraú, Sobral, Ceará, pela doação de duplicatas de amostras provenientes da Chapada da Ibiapaba e ao Dr. Ronald A. Pursell (The Pennsylvania State University) pela confirmação de algumas espécies.

\section{Referências bibliográficas}

BRASIL, MMA. 2002. Avaliação e identificação das áreas e ações prioritárias para a conservação, utilização sustentável e repartição dos benefícios da biodiversidade nos Biomas brasileiros. Ministério do Meio Ambiente, Brasília.

BRITO, A.E.R.M. \& PÔRTO, K.C. 2000. Guia de estudos de briófitas: Briófitas do Ceará. Edições Universidade Federal do Ceará, Fortaleza.

FERNANDES, A. 1990. Temas fitogeográficos. Stylos Comunicações, Fortaleza.

FIGUEIREDO, M.A. 1997. A cobertura vegetal do Ceará (Unidades Fitoecológicas). In Atlas do Ceará. Inplance, Fortaleza, p.28-29.

FLORSCHÜTZ, P.A. 1964. The mosses of Suriname. E.J. Brill, Leiden.

FUDALI, E. 2000. Some open questions of the bryophytes of urban areas and their responses to urbanization's impact. Perspectives in Environmental Sciences 2:14-18.

FUDALI, E. 2001. The ecological structure of the bryoflora of wroclaw's parks and cemeteries in relation to their localization and origin. Acta Societatis Botanicorum Poloniae 70:229-235.

GRADSTEIN, S.R., CHURCHILL, S.P. \& SALAZARALLEN, N. 2001. Guide to the Bryophytes of Tropical America. Memoirs of The New York Botanical Garden 86:1-577.

LISBOA, R.C.L. 1993. Musgos Acrocárpicos do estado de Rondônia. Museu Paraense Emílio Goeldi, Belém.

LISBOA, R.C.L. 1994. Adições à Brioflora do estado do Pará. Boletim do Museu Paraense Emílio Goeldi, Série Botânica 10:15-54.

LISBOA, R.C.L. \& ILKIU-BORGES, A.L. 1997. Novas ocorrências de Bryophyta (musgos) para o estado do Pará, Brasil. Acta Amazonica 27:81-102.

OLIVEIRA, H.C. \& ALVES, M.H. 2007. Adições à Brioflora do Estado do Ceará, Brasil. Rodriguésia 58:1-11. 
OLIVEIRA-E-SILVA, M.I.M.N. \& YANO, O. 2000. Musgos de Mangaratiba e Angra dos Reis, Rio de Janeiro, Brasil. Boletim do Instituto de Botânica 14:1-138.

PÔRTO, K.C. 1996. Briófitas. In Pesquisa Botânica Nordestina: progresso e perspectivas (E.U.S.B. Sampaio, S. Mayo \& M.R.V. Barbosa eds.). Sociedade Botânica do Brasil, Seção Regional de Pernambuco, Recife, p.97-109.

PURSELL, R.A. 2008. Fissidentaceae: Flora Neotropica Monograph 101:1-278.

SCHÄFER-VERWIMP, A. \& GIANCOTTI, C. 1993. New or interesting records of Brazilian bryophytes-IV. Hikobia 11:285-292.

SHARP, A.J., CRUM, H. \& ECKEL, P.M. (eds.). 1994. The moss flora of Mexico. Memoirs of The New York Botanical Garden 69:1-1113.

SOUZA, M.J.N. 1989. Geomorfologia. In Atlas do Ceará. Inplance, Fortaleza, p.14-15.

VITAL, D. \& PURSELL, R.A. 1992. New or otherwise interesting records of Brazilian bryophytes. The Journal of the Hattori Botanical Laboratory 71:119-122.

YANO, O. 1981. A checklist of Brazilian mosses. The Journal of the Hattori Botanical Laboratory 50:279-456.
YANO, O. 1984a. Checklist of Brazilian liverworts and hornworts. The Journal of the Hattori Botanical Laboratory 56:481-548.

YANO, O. 1984b. Briófitas. In Técnicas de coleta, preservação e herborização de material botânico (O. Fidalgo \& V.L.R. Bononi, coords). Instituto de Botânica, São Paulo, Manual n.4, p.27-30.

YANO, O. 1989. An additional checklist of Brazilian bryophytes. The Journal of the Hattori Botanical Laboratory 66:371-434.

YANO, O. 1995. A new additional annotated cheklist of Brazilian bryophytes. The Journal of the Hattori Botanic Laboratory 78:137-182.

YANO, O. 1996. A checklist of Brazilian bryophytes. Boletim do Instituto de Botânica 10:47-232.

YANO, O. 2006. Novas adições ao catálogo de Briófitas Brasileiras. Boletim do Instituto de Botânica 17:1-142.

YANO, O. \& COSTA, D.P. 1992. Novas ocorrências de briófitas no Brasil. In Anais 8 Congresso da Sociedade Botânica de São Paulo (R.R. Sharif, ed.). Campinas. p.33-45.

YANO, O. \& PÔRTO, K.C. 2006. Diversidade das briófitas das Matas Serranas do Ceará, Brasil. Hoehnea 33:7-40. 